\title{
A Cross sectional study to assess the DMFT, Oral Health related behavior and practice among the selected school of old Dhaka city, Bangladesh
}

\author{
SAAl-Jami ${ }^{*}$, AE Noor ${ }^{2 *}$
}

\section{AFFILIATION:}

1. Dr. Shaikh Abdullah Al- Jami

BDS, MPH, Assistant Professor \& Head,

Dept. of Dental Public Health, Delta Medical College \& Hospital,

Dental Unit, Dhaka, Bangladesh

Email: asstprofjami@gmail.com

ORCID ID: https://orcid.org/0000-0002-8528-79

\section{Dr. Ashek Elahi Noor}

BDS, MPH, Assistant Professor,

Dept. of Dental Public Health, Sapporo Dental College and

Hospital, Dhaka, Bangladesh

Email: rajet.elahi@gmail.com

ORCID ID: : https://orcid.org/0000-0002-2013-9523

\section{Article info.}

Received: 04 July 2021

Accepted: 28 July 2021

Volume: Vol-11, Issue-2, October 2021

DOI: https://doi.org/10.3329/updcj.v11i2.56090

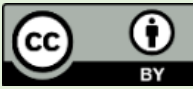

(C) Authors retain copyright and grant the journal right of first publication with the work simultaneously licensed under Creative Commons Attribution License CC - BY 4.0 that allows others to share the work with an acknowledgment of the work's authorship and initial publication in this journal.

https://creativecommons.org/licenses/by/4.0/

Publisher: Update Dental College, Dhaka, Bangladesh

Web: www.updatedentalcollege.edu.bd

E-mail: updcj@hotmail.com

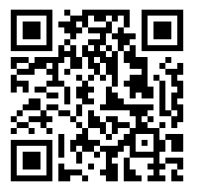

Scan QR code to see the latest issue

* Corresponding Author

Dr. Shaikh Abdullah Al- Jami

BDS, MPH, Assistant Professor \& Head, Dept. of Dental Public Health,

Delta Medical College \& Hospital, Dental Unit, Dhaka, Bangladesh Email: asstprofjami@gmail.com

ORCID ID: https://orcid.org/0000-0002-8528-79

\section{ABSTRACT:}

This cross-sectional type of descriptive study was conducted to assess the DMFT, oral health related behavior and practice in Rajer Deuri Government primary school in old Dhaka, Bangladesh.About 158 school children were selected by the purposive type of non-probability sampling technique. Face to face interview with questionnaire followed byChecklist. Out of 158 students, $78(49.4 \%)$ were $12-14$ years whereas maximum 80 (50.6\%) of them were male and $78(49.4 \%)$ were female. Againmajority students fathers were secondary level 34.2 and mothers were primary level passed $41.1 \%$. Maximum family income belongs to 81 (51.3\%) which is ranges from 10000-20000 Tk. Majority $89(56.3 \%)$ of the respondents never visited dentist. Again, maximum uses tooth paste with brushes $155(98.1 \%$ ) and also majority $64(40.5 \%)$. use a new tooth brush as long as last Maximum make a visit to the dentist about $62(39.2 \%)$ on having toothache. Moreover,though128 (81.0\%) agree that consumption of sugar in between meals causes dental caries but $130(82.3 \%)$ did not know about fluoride. Again, 64(40.5\%) respondents knows not cleaning their teeth may cause tooth decay. In addition, $89(56.3 \%)$ students don't know aboutgum bleeding while 52(32.9\%). About 116 (73.4\%) of the students didn't know how to protect their gumMoreover, $118(74.7 \%)$ \& $135(85.4 \%)$ of the respondents don't know about dental plaque \& calculus but $136(86.1 \%) \& 98(62.0 \%)$ knows sweet food \& soft drinks may affect dental health. Again, maximum 100(63.3\%) respondents think that the health of mouth impact on the health of body as well as their treatment is also important. About130 (82.3\%) of the respondents thinks that brushing teeth may prevent tooth decay while maximum $134(84.8 \%)$ of the respondents did not know using fluoride strength their teeth. Maximum, 122 (77.2\%) \& $134(84.8 \%)$ did not know using toothbrush\& floss help them preventing periodontal disease. Though $79(50.0 \%)$ of the respondents mentioned that using toothbrush \& flossing is the best method for prevention of tooth decay. About $89(56.3 \%)$ of the respondents brush their teeth more than 2 minutes. Maximum $83(52.5 \%) \& 129$ (81.6\%) of them did not know about the number of their permanent $\&$ deciduous tooth. About $136(86.1 \%)$ of the students did not know eruption time of $1^{\text {st }}$ permanent molar. Finally, 118 (74.7\%) out of 158 get knowledge about oral health from their family.There is a significant association between fathers \& mothers education with knowledge which resembles ( $P$ value is 0.001). Again, therewas a statistical significant association between cleaning in between teeth and their knowledge ( $P$ value is 0.012 ) and also on having toothache maximum did not visit to the dentist where ( $P$ value is $<0.001$ ). There is also statistical significant association between DMFT and their knowledge where ( $P$ value is 0.004 ).Finally, a comprehensive oral health educational program for both children and their parents are required to achieve this goal.

KEYWORDS: DMFT, dental caries, toothache, dental plaque, Periodontal disease INTRODUCTION:

Oral health is significantly related to oral health behaviors and knowledge. Oral health knowledge contributes to good oral health, but unless attitudes and habits are developed and put into practice, little will be gained. ${ }^{1}$ It is important to review the knowledge, attitude and practices of the oral health of adolescents, even though they are educated, with the objectives of inculcating healthy lifestyles practices to last for a lifetime. Individuals who hold favorable oral health related beliefs over time have better oral health in their later years than those who do not. This implies that changing beliefs should result in changes in behaviors. ${ }^{2}$ Many studies have been conducted on perceived oral health, but have mostly concentrated on adults and old people. ${ }^{3}$ Dental disease is also 
very common in our country. Caries, gingivitis and periodontitis are the common dental disease. Lack of awareness about the dental disease and proper treatment facilities are the main cause of poor dental condition. Improper tooth brushing among the child age group and poor socioeconomic status are the main cause of developing dental disease commonly in rural or in urban area also. ${ }^{4}$ Dental caries occurs due to demineralization of enamel and dentine (the hard tissues of the teeth) by organic acids formed by bacteria in dental plaque through the anaerobic metabolism of sugars derived from the diet. ${ }^{5}$ When sugars or other fermentable carbohydrates are ingested, the resulting fall in dental plaque $\mathrm{pH}$ caused by organic acids increases the solubility of calcium hydroxyl apatite in the dental hard tissues and demineralization occurs as calcium is lost from the tooth surface. The deciduous teeth erupt from 6 months and are lost by the early teens. The permanent dentition replaces the deciduous dentition from the age of 6 years and is complete by age 21 . Teeth are most susceptible to dental caries soon after they erupt; therefore, the peak ages for dental caries are 2 to 5 years for the deciduous dentition and early adolescence for the permanent dentition. ${ }^{6}$ In modern dentistry, "prevention" receives special attention and precedes treatment. Prevention is easier and more economical. Now days, in advanced societies, through simple prevention techniques such as hygiene training, fluoride therapy, tooth brushing and supplementary instruments, caries prevalence andperiodontal diseases have been reduced significantly. As a result the needs of treatments, that are mostly expensive and time consuming, have been decreased. ${ }^{7}$ The behavior of the people, in each society, is influenced by their knowledge and tendencies; on the other hand, the beliefs and tendencies of each society are also influenced by people's behavior. Naturally, social and individual hygiene, depend on people's knowledge. In order to promote useful hygienic habits among people and change their behavior, a comprehensive and accurate program is necessary. Such an approach leads us to achieve our cultural goals. One of the most effective factors, to reach these goals is to invest and pay special attention on oral hygiene training in the schools to enhance the development and quality of life in our country.

MATERIALS AND METHODS:

A descriptive type of cross-sectional study was conducted in Rajer Deuri Government primary school, Old Dhaka, Bangladesh. The study population was 158 school children. The samples were selected by purposive type of nonprobability sampling technique. Data were collected through semi-structured questionnaire; check list and examination tools (dental caries probe, dental mouth mirror, dental tweezers, hand gloves, face mask, napkin, torch for proper illumination, antiseptic solution, etc). Questionnaire was filled by taking face to face interview, and checklist was fulfilled by

21| P a g e oral examination and inspection. Data was analyzed and prepared by using SPSS version 26. Then data was presented in tables and figures. Written permission was taken from concerned authorities of all the schools. All instruments were sterilized. Collected data were kept confidential and used only for this research purpose.

RESULTS:

The result of the study have been described as follows-

Table 01: Distribution of the students by their sociodemographic characteristics. $(n=158)$

\begin{tabular}{|c|c|c|}
\hline Age group & $\begin{array}{l}6-8 \text { years-5.7\%, } 9-11 \text { years-38.6\%,12-14 } \\
\text { years-49.4\%,15-18years } 6.3 \%\end{array}$ & \\
\hline Gender & Male-50.6\% and female-49.4\% & \\
\hline $\begin{array}{l}\text { Parent's } \\
\text { Education }\end{array}$ & $\begin{array}{ll}\text { Fathers' } & \text { Illiterate-20.9\%, Primary-33.5\%, } \\
& \text { Secondary-34.2\%, Graduate and } \\
& \text { above-11.4\% }\end{array}$ & $0.001^{\mathrm{s}}$ \\
\hline
\end{tabular}

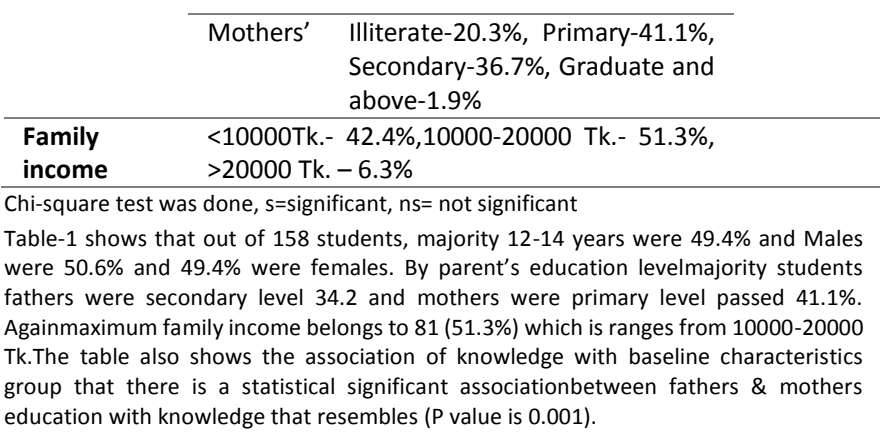

Table-2: Distribution of the study respondents by oral Health related Behavior\& practice $(n=158)$

\begin{tabular}{|c|c|c|c|}
\hline Oral Health Behavior & Frequency & $\begin{array}{l}\text { Percentage } \\
(\%)\end{array}$ & P value \\
\hline \multicolumn{4}{|l|}{ How often do you clean teeth? } \\
\hline Morning only & 64 & 40.5 & \\
\hline Evening only & 4 & 2.5 & \\
\hline $\begin{array}{l}\text { Morning and } \\
\text { evening }\end{array}$ & 87 & 55.1 & \\
\hline Occasionally & 3 & 1.9 & \\
\hline \multicolumn{4}{|l|}{$\begin{array}{l}\text { How many times you clean your } \\
\text { teeth? }\end{array}$} \\
\hline One time & 65 & 41.1 & \\
\hline Two time & 91 & 57.6 & \\
\hline Occasionally & 1 & .6 & \\
\hline Never clean & 1 & .6 & \\
\hline \multicolumn{4}{|l|}{ Your clean your teeth using: } \\
\hline $\begin{array}{l}\text { Brush+ } \\
\text { Toothpaste }\end{array}$ & 155 & 98.1 & \\
\hline Datun & 2 & 1.3 & \\
\hline Others & 1 & .6 & \\
\hline \multicolumn{4}{|l|}{ Your use a new tooth brush } \\
\hline Every 3 months & 61 & 38.6 & \\
\hline Every 6 months & 5 & 3.2 & \\
\hline As long as last & 64 & 40.5 & \\
\hline Others & 28 & 17.7 & \\
\hline
\end{tabular}

Website: https://www.banglajol.info/index.php/UpDCJ 
For cleaning in between teeth

you use

\begin{tabular}{cll}
\hline Dental floss & 3 & 1.9 \\
\cline { 1 - 3 } toothpick & 48 & 30.4 \\
\hline Brush & 67 & 42.4 \\
\hline Nothing & 40 & 25.3 \\
\hline You visit your dentist & & \\
\hline Every year & 1 & .6 \\
\hline $\begin{array}{l}\text { Only when } \\
\text { needed }\end{array}$ & 68 & 43.0 \\
\hline Never & 89 & 56.3 \\
\hline
\end{tabular}

On having a toothache what you did

$\begin{array}{llc}\begin{array}{l}\text { Use a home } \\ \text { remedy }\end{array} & 17.1 & <0.001^{\mathrm{s}} \\ \begin{array}{l}\text { Make visit to the } 62 \\ \text { dentist }\end{array} & 39.2 \\ \begin{array}{l}\text { Make visti to the } \\ \text { doctor }\end{array} & 19 & 12.0 \\ \text { Nothing } & 50 & 31.6\end{array}$

\section{Chi-square test was done, $\mathrm{s}=$ significant, $\mathrm{ns}=$ not significant}

Table-2: The table shows that out of 158 respondents, majority of the students $87(55.1 \%)$ clean their teeth at the morning \&evening whereas 91(57.6\%) clean their teeth twice daily. On the other hand, $89(56.3 \%)$ of the respondents never visited dentist while for cleaning in between teeth they uses brush maximum that is $67(42.4 \%)$. Again, maximum uses tooth paste with brushes $155(98.1 \%)$ and also majority $64(40.5 \%)$. use a new tooth brush as long as last Maximum make a visit to the dentist about $62(39.2 \%)$ on having toothache.Also there is a statistical significant association between cleaning in between teeth and their knowledge ( $P$ value is 0.012 ) and on having toothache maximum did not visit to the dentist where ( $P$ value is $<0.001$ )

Table-3: Distribution of the study respondents by oral health knowledge $(n=158)$

\begin{tabular}{|c|c|c|}
\hline Oral health knowledge & Frequency & Percentage (\%) \\
\hline \multicolumn{3}{|l|}{$\begin{array}{l}\text { Do you not agree that consumption } \\
\text { of sugar in between meals causes } \\
\text { dental caries? }\end{array}$} \\
\hline Yes & 128 & 81.0 \\
\hline No & 27 & 17.1 \\
\hline Do not know & 3 & 1.9 \\
\hline \multicolumn{3}{|l|}{ Do you know about fluoride } \\
\hline Yes & 28 & 17.7 \\
\hline No & 130 & 82.3 \\
\hline \multicolumn{3}{|l|}{ If yes, where it is found } \\
\hline Toothpaste & 19 & 67.9 \\
\hline Drinking water & 4 & 14.3 \\
\hline Sea food & 5 & 17.9 \\
\hline \multicolumn{3}{|l|}{$\begin{array}{l}\text { Not cleaning your teeth everyday can } \\
\text { cause }\end{array}$} \\
\hline Decay & 64 & 40.5 \\
\hline Gum disease & 19 & 12.0 \\
\hline Bad breath & 15 & 9.5 \\
\hline All of the previous & 35 & 22.2 \\
\hline Causing nothing & 3 & 1.9 \\
\hline Don't know & 22 & 13.9 \\
\hline \multicolumn{3}{|l|}{ What does gum bleeding means } \\
\hline Healthy gum & 11 & 7.0 \\
\hline Inflamed gum & 52 & 32.9 \\
\hline Using vitamin e & 6 & 3.8 \\
\hline Don'tknow & 89 & 56.3 \\
\hline \multicolumn{3}{|l|}{$\begin{array}{l}\text { How do your protect yourself from } \\
\text { gum bleeding }\end{array}$} \\
\hline toothpaste & 33 & 20.9 \\
\hline
\end{tabular}

22| P a g e
Dr. Shaikh Abdullah al-Jami et al.

\begin{tabular}{clll}
\hline and brush & & \\
\hline Using soft food & 2 & 1.3 \\
\hline Using vitamin E & 7 & 4.4 \\
\hline Don't know & 116 & 73.4 \\
\hline What is dental plaque & & \\
\hline Soft debris on tooth & 34 & 21.5 \\
\hline stain on teeth & 3 & 1.9 \\
\hline Hard debris on teeth & 3 & 1.9 \\
\hline Don't know & 118 & 74.7 \\
\hline What is calculus & & \\
\hline Soft debris on tooth & 9 & 5.7 \\
\hline Hard debris on teeth & 14 & 8.9 \\
\hline Don't know & 135 & 85.4 \\
\hline Do sweets affect dental health & & \\
\hline Yes & 136 & 86.1 \\
\hline No & 8 & 5.1 \\
\hline Don't know & 14 & 8.9 \\
\hline Do soft drink affect dental health & & \\
\hline Yes & 98 & 62.0 \\
\hline No & 35 & 22.2 \\
\hline Don't know & 25 & 15.8 \\
\hline
\end{tabular}

Does the health of mouth impact on

the health of body?

\begin{tabular}{cll}
\hline Yes & 100 & 63.3 \\
\hline No & 18 & 11.4 \\
\hline Don't know & 40 & 25.3 \\
\hline
\end{tabular}

Treatment of toothache is an

important as any

\begin{tabular}{cll}
\hline Yes & 100 & 63.3 \\
\hline No & 13 & 8.2 \\
\hline Don't know & 45 & 28.5 \\
\hline Brushing teeth prevent dental decay & & \\
\hline Yes & 130 & 82.3 \\
\hline No & 12 & 7.6 \\
\hline Don't know & 16 & 10.1 \\
\hline Using fluoride strength the teeth & & \\
\hline Yes & 19 & 12.0 \\
\hline No & 5 & 3.2 \\
\hline Don't know & 134 & 84.8 \\
\hline
\end{tabular}

Using toothbrush help preventing

periodontal disease

\begin{tabular}{cll}
\hline Yes & 27 & 17.1 \\
\hline No & 9 & 5.7 \\
\hline Don't know & 122 & 77.2 \\
\hline $\begin{array}{c}\text { Using floss helps in preventing } \\
\text { periodontal disease }\end{array}$ & \\
\hline Yes & 10 & 6.3 \\
\hline No & 14 & 8.9 \\
\hline Don't know & 134 & 84.8 \\
\hline
\end{tabular}

In your opinion which one of these is

the best method for prevention of

tooth decay

\begin{tabular}{cll}
\hline Limiting sugar snack & 16 & 10.1 \\
\hline $\begin{array}{l}\text { Chewing sugarless } \\
\text { gum }\end{array}$ & 2 & 1.3 \\
\hline Brushing and flossing & 79 & 50.0 \\
\hline $\begin{array}{l}\text { Visiting dentist every } \\
\text { 6 months }\end{array}$ & 5 & 3.2 \\
\hline Don't know & 56 & 35.4 \\
\hline How long do you brush your teeth & & \\
\hline 1 minute & 23 & 14.6 \\
\hline 2 minute & 46 & 29.1 \\
\hline
\end{tabular}

Website: https://www.banglajol.info/index.php/UpDCJ 


\begin{tabular}{cll}
\hline \hline $\mathbf{2}$ minute & 89 & 56.3 \\
\hline How many permanent teeth & & \\
\hline $\mathbf{2 2}$ & 5 & 3.2 \\
\hline $\mathbf{3 2}$ & 70 & 44.3 \\
\hline Don't know & 83 & 52.5 \\
\hline How many deciduous teeth & & \\
\hline $\mathbf{2 2}$ & 8 & 5.1 \\
\hline $\mathbf{3 2}$ & 3 & 1.9 \\
\hline $\mathbf{2 0}$ & 18 & 11.4 \\
\hline Don't know & 129 & 81.6 \\
\hline
\end{tabular}

\begin{tabular}{llll}
\hline $\begin{array}{l}\text { At what age first permanent molar } \\
\text { erupt }\end{array}$ & & \\
\hline & $\mathbf{6}$ years & 4 & 2.5 \\
\hline $\mathbf{7}$ years & 8 & 5.1 \\
\hline 8 years & 10 & 6.3 \\
\hline Don't know & 136 & 86.1 \\
\hline
\end{tabular}

\begin{tabular}{llll}
$\begin{array}{l}\text { Where did you get knowledge about } \\
\text { oral health }\end{array}$ & & 86.1 \\
\hline & Friends & 2 & \\
\hline Family & 118 & 1.3 \\
\hline Internet and TV & 14 & 74.7 \\
\hline Newspaper & and & 11 & 8.9 \\
\hline Magazine & & 7.0 \\
\hline Dentist & 9 & \\
\hline No resource & 2 & 5.7 \\
\hline Do not know & 2 & 1.3 \\
\hline
\end{tabular}

Table-3: The table shows that out of 158 respondents, though $128(81.0 \%)$ agree that consumption of sugar in between meals causes dental caries but $130(82.3 \%)$ did not know about fluoride. Again, 64(40.5\%) respondents knows not cleaning their teeth may cause tooth decay. In addition, 89(56.3\%) students don't know aboutgum bleeding while 52(32.9\%). About 116 (73.4\%) of the students didn't know how to protect their gum. Moreover, $118(74.7 \%) \& 135(85.4 \%)$ of the respondents don't know about dental plaque \& calculus but $136(86.1 \%) \& 98(62.0 \%)$ knows sweet food \& soft drinks may affect dental health. Again, maximum 100(63.3\%) respondents think that the health of mouth impact on the health of body as well as their treatment is also important. About130 (82.3\%) of the respondents thinks that brushing teeth may prevent tooth decay while maximum 134 $(84.8 \%)$ of the respondents did not know using fluoride strength their teeth. Maximum, $122(77.2 \%) \& 134(84.8 \%)$ did not know using toothbrush\& floss help them preventing periodontal disease. Though $79(50.0 \%)$ of the respondents mentioned that using toothbrush \& flossing is the best method for prevention of tooth decay. About $89(56.3 \%)$ of the respondents brush their teeth more than 2 minutes. Maximum $83(52.5 \%) \& 129$ $(81.6 \%)$ of them did not know about the number of their permanent \& deciduous tooth About $136(86.1 \%)$ of the students did not know eruption time of $1^{\text {st }}$ permanent molar. Finally, 118 (74.7\%) out of 158 get knowledge about oral health from their family.

Table-4: Total DMFT of the student $(n=158)$

\begin{tabular}{|c|c|c|c|c|}
\hline DMFT & Frequency & $\begin{array}{l}\text { Percentage } \\
\text { (\%) }\end{array}$ & Mean $\pm S D$ & $P$ value \\
\hline $\begin{array}{l}\text { Decayed } \\
\text { (D) }\end{array}$ & 51 & 32.3 & $0.80 \pm 1.46$ & \\
\hline $\begin{array}{l}\text { Missing } \\
\text { (M) }\end{array}$ & 25 & 15.8 & $0.28 \pm 0.81$ & \\
\hline Filled (F) & 3 & 1.9 & $0.04 \pm 0.31$ & \\
\hline DMFT & 79 & 38.0 & $1.13 \pm 1.87$ & $0.004^{s}$ \\
\hline
\end{tabular}

Chi-square test was done, $\mathrm{s}=$ significant, $\mathrm{ns}=$ not significant

Table-4: The table shows that out of 158 respondents, the total DMFT is found out to be 79 with 51decayed teeth, 25 missing teeth and 3 filled teeth. The mean DMFT is found out to be $1.13 \pm 1.87$ with mean decayed being $0.80 \pm 1.46$, mean missing $0.28 \pm 0.81$ and mean filled teeth $0.04 \pm 0.31$ and also statistical significant association between DMFT and their knowledge where ( $\mathrm{P}$ value is 0.004 ).

Figure-1: Distribution of the study respondents by knowledge $(n=158)$

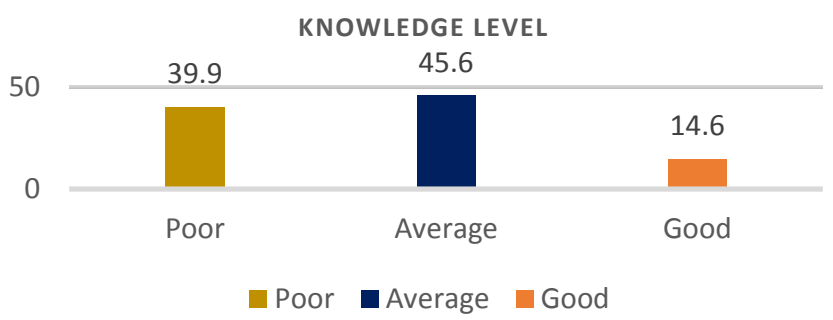

Figure1: The figure shows that out of 158 respondents, maximum 72(45.6\%) respondents have average knowledge (10-15) while only $23(14.6 \%)$ has good knowledge (>15).

\section{DISCUSSION:}

This cross-sectional descriptive study was carried out assess the DMFT, oral health related behavior and practice among Rajer Deuri Government primary school children. Majority 1214 years were $49.4 \%$ and Males were $50.6 \%$ and $49.4 \%$ were females. By parent's education levelmajority students fathers were secondary level 34.2 and mothers were primary level passed $41.1 \%$. Againmaximum family income belongs to 81 (51.3\%) which is ranges from taka 10000-20000.

A cross sectional study was conducted in 6 schools serving low middle socio-economic strata in Bangalore, India reveals that Prevalence of dental pain was $15.6 \%(n=194)$. Impact on daily activities was reported by $66 \%$. Mean DMFT and DMFS was 1.80 and 2.11. Mean deft and defs was 2.47 and 3.41. Prevalence of dental pain is associated with brushing behavior, consumption of sweets and deciduous dental caries experience, showing need for further attention to these conditions and a need to strengthen preventive and therapeutic dental service. ${ }^{8}$ Furthermore, majority of the students 87 (55.1\%) clean their teeth at the morning and evening whereas $91(57.6 \%)$ clean their teeth twice daily. On the other hand, $89(56.3 \%)$ of the respondents never visited dentist while for cleaning in between teeth they uses brush maximum that is $67(42.4 \%)$. Again, maximum uses tooth paste with brushes 155(98.1\%) while duration of a new tooth brush as long as last for $64(40.5 \%)$ which resemble the majority. The main feature resembles the maximum make a visit to the dentist about 62(39.2\%) but unfortunately only 50(31.6) respondents did not have a visit to the dentist.Furthermore, another descriptive cross-sectional observational study was conducted among 100 schools going slum children in Mirpur, Dhaka where conventional sampling method was used. Maximum students brushed once a day before bedtime which differs from our study. Dental caries was $55 \%$. This is quite higher than our study. The prevalence of caries was directly related to low frequency of brushing. ${ }^{9}$

Moreover, though $128(81.0 \%)$ agree that consumption of sugar in between meals causes dental caries but $130(82.3 \%)$

Website: https://www.banglajol.info/index.php/UpDCJ 
did not know about fluoride. Again, 64(40.5\%) respondents know not cleaning their teeth may cause tooth decay. Moreover, 136(86.1\%) and 98(62.0\%) knows sweet food and soft drinks may affect dental health. Again, maximum $100(63.3 \%)$ respondents think that the health of mouth impact on the health of body as well as their treatment is also important. About130 (82.3\%) of the respondents thinks that brushing teeth may prevent tooth decay while maximum 134 (84.8\%) of the respondents did not know using fluoride strength their teeth. Though $79(50.0 \%)$ of the respondents mentioned that using toothbrush and flossing is the best method for prevention of tooth decay.

Where as a cross-sectional study was carried out in Qatar from October 2011 to April 2012 about 2200 school children aged 12-14 years reveals that Only (25.8\%) of children reported a high level of oral health knowledge which is quite dissimilar to our study finding. After each meal, tooth brushing was observed by a very low percentage of children (3.7\%). About $44.6 \%$ of children recognized dental floss as a cleaning device for between the teeth. A large number of children (32.5\%) thought incorrectly that one must visit the dentist only in case of pain. A great majority was not aware of cariogenic potential of soft drinks (39\%) and sweetened milk (97.8\%). Less than half (38.9\%) of children actually had heard about fluoride. Only $(16.8 \%)$ correctly answered the question about sign of tooth decay. Slightly, less than half (48.4\%) could not define the meaning of plaque. Parents were the most popular (69.1\%), source of oral health information for the children. ${ }^{10}$

There was a statistical significant between fathers \& mothers education with knowledge that resembles ( $P$ value is 0.001 ). Again, therewas a statistical significant association between cleaning in between teeth and their knowledge ( $P$ value is 0.012) and on having toothache maximum did not visit to the dentist where ( $P$ value is $<0.001$ ). Finally, therewas a statistical significant association between DMFT and their knowledge where ( $P$ value is 0.004 ).

A cross sectional study associated with dental caries among students from Santa Cruz do Sul, Brazil was conducted in a random sample of 623 students of both genders, aged 10-17 years old. The DMFT value was 1.1-2.4 which is significantly higher than DMFT (1.48) that we have found. A significantly higher number of children had poor oral hygiene status, moderate to severe caries experience as a result of less frequency of brushing, poor oral hygiene knowledge and irregular dental checkup. ${ }^{11}$ In this cross sectional study we found the total DMFT is found out to be 79 with 51decayed teeth, 25 missing teeth and 3 filled teeth. The mean DMFT is found out to be $1.13 \pm 1.87$ with mean decayed being $0.80 \pm 1.46$, mean missing $0.28 \pm 0.81$ and mean filled teeth $0.04 \pm 0.31$. Maximum $72(45.6 \%)$ respondents have average knowledge (10-15) while only 23 (14.6\%) has good knowledge $(>15)$.

24| P a g e
A cross sectional study was conducted between June 2014 \& May 2015 at Taif University Outpatient Clinics, Saudi Arabia on the age group of 18 years among 385 male \& female who were willing to participate. The mean DMFT was 6.55 which is very higher than DMFT (1.48) that we found. A high prevalence of dental caries was observed among the participants. High incidence of dental caries related to lack of proper oral health education and dental checkup. ${ }^{12}$

\section{CONCLUSION:}

Oral health is an important part of our life. But lack of proper knowledge it is not treated carefully. The status of oral health is low in lower class, poor, uneducated population and especially in children. It is needed to be making them conscious about the importance of good oral health because sometimes the small injury can cause of life threatening condition such as oral cancer. Results of this study suggest that oral health knowledge and practice among study participants were poor and needs to be improved. Findings of the present study also show that utilization of dental service is mainly for pain relief. The results also suggest that simple preventive oral health measures among study participants like brushing twice a day is not a norm. Based upon these findings, systematic community-oriented oral health promotion programs are needed to target lifestyles and the needs of school children. Oral diseases are major public health problem in school children. Therefore, the students should maintain their oral hygiene by regular tooth brushing and they should visit the dentist for their good oral health status. School physician and nurse have to take an active role in reporting oral health problem to families and prescribe appropriate strategies for personal hygiene. Comprehensive oral health educational programs for both children and their parents are required to achieve this goal.

CONFLICT OF INTEREST: Author declared no conflict of interest

\section{Citation:}

Shaikh Abdullah Al- Jami, \& Ashek Elahi Noor. A Cross sectional study to assess the DMFT, Oral Health related behavior and practice among the selected school of old Dhaka city, Bangladesh. Update Dental College Journal, 11(2), 20-26. https://doi.org/10.3329/updcj.v11i2.56090

\section{REFERENCES:}

1. McGrath C, Sham AS, Ho DK, Wong JH. The impact of dental neglect on oral health: A population based study in Hong Kong. Int Dent J. 2007;57:3-8 https://doi.org/10.1111/j.1875-595X.2007.tb00111.x PMid:17378343

2. Nagesh $\mathrm{H}$. Oral Health related knowledge, attitude and practice [KAP] among 16-18 yr old students of 4 pre-university colleges in Bangalore south India. RGUHS J Dent Sci. 2008;2:12-8.

Website: https://www.banglajol.info/index.php/UpDCJ 
3. Ostberg AL, Jarkman K, Lindblad U, Halling A. Adolescents' perceptions of oral health and influencing factors: A qualitative study. ActaOdontol Scand. 2002;60:167-73. https://doi.org/10.1080/000163502753740197 PMid:12166911

4. Fakir MM, Alam KMU, Mamun FA, Sarker N. A Survey on Oral Health Condition in Primary School Children. Medicine today 2010; 22(02): 70-72.

https://doi.org/10.3329/medtoday.v22i2.12436

5. Mamun MA \& Ahmad MS. Knowledge and Practice about Oral Hygiene of School Children in Northern Region of Bangladesh. Survey 2014; Department of Dental Public Health, Rangpur Dental College, Rangpur, Bangladesh.

6. Poul EP. Integrated prevention of oral and chronic disease- the challenges to dental public health. European Association of Dental Public Health, Meeting 2006.www.eadph.orgviwed on 15/06/2015.

7. Smith AJ, Murray PE, Sloan AJ, Matthews JB, Zhao S. Transdentinal stimulation of tertiary dentinogenesis. Advances in dental research. $2001 \quad$ Aug;15(1):51-4. https://doi.org/10.1177/08959374010150011301 PMid:12640740

8. Saheer A, et al. Dental pain among 10-15 year old children attending oral health promoting school: A cross sectional study. Jint SOC Prev community Dent 2015 Dec; (Suppl 2): S101-6 doi : 10.4103/2231-0762. 172948

9. MishuMp, et al . Relationship between untreated Dental caries and weight and Height of 6-12 years old primary School children in Bangladesh. International Journal of Dentistry (2013) https://doi.org/10.1155/2013/629675 PMid:23690777 PMCid:PMC3639635

10. Jboor DH, Al-Darwish MS, NurU.Dent J (Basel), Oral Cancer Knowledge, Attitude, and Practice of Dentists in the State of Qatar.2019 Apr 11;7(2):43. https://doi.org/10.3390/dj7020043 PMid:30978958 PMCid:PMC6631219

11. Borges T.S. , Schwanke N.L., Reuter C.P. , Neto L.K. , Burgos M.S. ; A survey of students from southern Brazil ; Rev Paul Pediatr. 2016; 34(4): 489-494. https://doi.org/10.1016/j.rppede.2016.02.013 PMCid:PMC5176071

12. Kaplan HI, Saddock BJ etal. An assessment of dental caries at University of Arabia; a cross sectional study; J community Med Health Edu 58: 7-12. 